\title{
КОНСТИТУЦІЙНІ ЗАСАДИ РЕАЛІЗАЦІЇ ПРАВА НА МИРНІ ЗІБРАННЯ В СУЧАСНІЙ УКРАЇНІ
}

Конєв І. $\epsilon$.

Стаття присвячена основоположним правам людини, до складу яких входить і право на мирні зібрання, що є невід'ємним та закріпленим в Конституції України та багатьох міжнародних актах. Досліджуються проблеми закріплення цього права на законодавчому рівні. Наводиться практика Європейського суду з прав людини. Актуальність вирішення прогалин у нормативній базі країни щодо реалізації права на мирні зібрання на сьогодення та детальний аналіз перспективи існування такого закону в майбутньому.

Ключові слова: Венеціанська комісія, основоположні права, Конституційні гарантії, практика ЄСПЛ, законопроекти, обмеження права, заходи охорони, реалізація права.

Статья посвящена основополагающим правам человека, в число которых входит и право на мирное собрание, что является неотъемлемым и закреплённым в Конституции Украины и многих международных актах. Исследуются проблемы закрепления этого права на законодательном уровне. Приводится практика Европейского суда по правам человека. Актуальность решения пробелов в нормативной базе страны по реализации права на мирные собрания на сегодняшний день и детальный анализ перспективы суще ствования такого закона в будущем.

Ключевые слова: Венецианская комиссия, основополагающие права, Конституционные гарантии, практика ЕСПЧ, законопроекты, ограничение права, меры охраны, реализация права.

The article is devoted to the fundamental human rights, which includes the right to peaceful assembly, which is inalienable and enshrined in the Constitution of Ukraine and many international acts. The problems of consolidating this right at the legislative level are investigated. The practice of the European Court of Human Rights is given. The relevance of addressing gaps in the country's regulatory framework for the implementation of the right to peaceful assembly today and detailed analysis of the future existence of such a law.

Two draft laws on the right to peaceful assembly are compared. Also highlights all the advantages and disadvantages of the norms of draft laws. Moreover, the article contains the relevant recommendations of Venice Commission and personally our views on these bills. Furthermore, the article focuses on the judicial branch of power, which has the exclusive right to resolve disputes on the implementation by citizens of the right to peaceful assembly. Besides, ways of settling these claims are determined by the Ukrainian courts, based on international law and its experience. As well as based on the state's own experience of the courts in resolving disputes in this area.

Meanwhile, there is a problem with the legislative consolidation of the right to peaceful assembly and the considerable need to address such a gap in the national legislation of the country. The need to introduce a special law to allow a comprehensive settlement of disputes in this area is argued. Also different opinions of the society on this subject are covered. There are numerous examples of norms that can serve as guarantees and a solid foundation for the implementation of the law on peaceful assembly in the future. Such examples include the most important law of our country, which has the highest legal force, namely the Constitution of Ukraine. Examples are given of many provisions of the Constitution that allow us to assert significant changes and the prospect of adopting a special law on peaceful assembly.

The author focused on the need for a law on peaceful assembly to be adopted as soon as possible, because rapid globalization processes are pushing Ukraine to improve the legal framework in accordance with the generally accepted European and international standards, which will not only allow to fill the gap in the field of peaceful assembly, but also to form civil society.

Key words: Venice Commission, fundamental rights, constitutional guarantees, practice ECHR, draft laws, restriction of rights, security measures, implementation of law.

Постановка проблеми. Наразі в нашому законодавстві не має відповідного спеціального закону, який би чітко врегульовував право збиратися мирно, без зброї і проводити мітинги, походи, демонстрації та інші форми зібрань. Реалізація такого права регламентована тільки ст. 39 Конституції України та багатьма міжнародними договорами, згода на обов'язковість яких надана Верховною Радою України згідно зі ст. 9 Конституції України [1]. Тому перед парламентом постає нагальна проблема у якомога швидшому унормуванні таких видів відносин суспільства в національному законодавстві, щоб мати змогу в подальшому вирішувати питання реалізації права мирного зібрання особами вже на законних підставах.

Повсякчас держава бере на себе обов'язок збереження громадського порядку, охорони прав, свобод і законних інтересів громадян. Із цього випливає, що держава повинна створювати умови й механізми реалізації прав населення через органи державної влади, які гарантують реалізацію їх у відповідних межах, установлених законодавством. Тож для втілення в життя будьякого права, регламентованого заздалегідь Конституцією, не слід забувати, що воно не повинне порушувати на конституційні права інших осіб чи посягати на них.

Аналіз останніх досліджень і публікацій. Як зазначалося, в Конституції України закріплено багато норм, які слугують основоположними принципами для регулювання державою процесами як усередині країни, так і ззовні. Але єдиного їх закріплення в Основному Законі не достатньо, хоч він і має вищу юридичну силу. Проблематика такого питання постає у тому, що такі норми не $\epsilon$ деталізованими, тому для подальшого функціонування права необхідно створення спеціального закону, який би визначав усю повноту і різноманітність життєвих обставин і давав змогу застосовувати його на практиці. Разом із цим принциповим залишається питання, чи прийнято всі закони, які відображають конституційні норми, та чи повністю відповідають вони їм і міжнародним договорам. На жаль відповідь очевидна, оскільки

Конєв І. Є., 2019 
досі не прийнято жодного нормативно-правового акту, який би врегульовував право на мирні зібрання.

Предметом дослідження науковців П.М. Любченко, О.В. Васковської, В.Г. Поліщука, О.В. Петришина були правові проблеми реалізації права на мирні зібрання. Також окремі аспекти цього питання в Україні вивчали юристи К.М. Магнушевська, М.С. Смокович, М.А. Лебідь, Н.Н. Ахтирська.

Метою статті $\epsilon$ обґрунтування необхідності прийняття закону «Про мирні зібрання» для поліпшення законодавчого регулювання прав осіб відповідними інстанціями влади. Важливість регламентації прав і обов'язків організаторів (учасників зібрання) для громадськості й держави. Аналіз якостей запланованих обмежень і концептуальних засад правового регулювання права на мирні зібрання в Україні.

Виклад основного матеріалу. Якщо звернутися до історії становлення основоположних прав людини, то вони були сформовані задля мети захисту законних інтересів приватних осіб від посягань з боку держави. Такий собі захисний механізм був сформульований Єлінеком як «суб' єктивне право», що становить собою можливість певного суб'єкта правовідносин вимагати від держави певних дій або ж утримання від них [2, с. 66]. У такий спосіб сформульована «захисна конструкція» дозволяє особі вимагати дотримання основоположних прав і свобод та домагатися їх реалізації через суд. Завдяки цьому створюється простір, у якому приватна особа відчуває себе захищеною від посягань держави та має змогу вільно користуватися своїми правами, висловлюватися, мати власну думку з тих чи інших питань.

Право на мирні зібрання $є$ невід'ємним від основоположних прав людини, оскільки зазначена ст. 39 Конституції України нерозривно пов'язана зі ст. 34 Конституції України, де зазначається, що кожному гарантується право на свободу думки і слова та на вільне вираження своїх поглядів і переконань [1]. Згідно з цією нормою, кожен має право поширювати інформацію у спосіб на свій власний вибір. Слід акцентувати увагу на вислів «в іншій спосіб», що може тлумачитися дуже широко й мати позитивні перспективи для прийняття в майбутньому закону «Про мирні зібрання», оскільки такий спосіб поширення інформації може існувати не тільки в письмовому або усному вигляді, а й у різноманітних формах вираження своєї думки через мирні зібрання: хода, процесія, костюмований виступ, концерт, пікет, флешмоб, страйк працівників, зібрання політичних партій та союзів тощо. Висновок: право на мирні зібрання $\epsilon$ складовою основоположних прав людини, i єдиного їх закріплення в Основному Законі та Конвенції з прав людини $є$ недостатнім для всебічного вирішення питання в цій сфері. Це поняття дуже контроверсійне в його вирішенні й у випадках необхідних обмежень, адже позови до суду з цього питання $\epsilon$, а відповідного нормативного акта, який би регулював ці відносини, досі немає, і весь тягар вирішення таких спорів падає на відповідальність суддів.

Виходячи зі складних реалій щодо значних законодавчих прогалин у нашій державі стосовно мирних зібрань, зробимо висновок, що державним інстанціям потрібно керуватися існуючими актами або нормами, що зачіпають проблему вирішення спорів у цій сфері правовідносин, адже безперечним $€$ той факт, що суду дуже важко вирішувати спори, коли вони не прописані жодним нормативно-правовим документом. Тому залишається керуватися ст. 11 Конвенції про захист прав людини та основоположних свобод, ст. 185-185 КУпАП, постановою Пленуму Вищого адміністративного суду України «Про практику застосування адміністративними судами законодавства під час розгляду та вирішення справ стосовно реалізації права на мирні зібрання (збори, мітинги, походи, демонстрації тощо)» та рішеннями Європейського суду з прав людини [3].

Звертаючи увагу на різноманітні міркування, багато хто висловлює своє незадоволення щодо внесення законопроектів та закликає не приймати закон, оскільки, на їхню думку, регламентація такого права в Основному Законі країни достатньо сформульована для втілення його в життя, тому немає потреби деталізувати механізм мирних зібрань у спеціальному акті. На нашу думку, таке судження $\epsilon$ помилковим, оскільки будьякі відносини повинні завжди регулюватися законами задля можливості подальшого їх вирішення в судовому провадженні. Безумовно, коли певне питання законодавчо неврегульоване, це дає простір для численних його трактувань зі сторони політиків або активістів у свою користь, що призводить до зловживання правом у власних інтересах. У цьому разі набагато простіше, цілеспрямовано користуючись законодавчою прогалиною, перекладати відповідальність на інших осіб, а саме на суддів, які розглядають справи про мирні зібрання. У цьому контексті слід навести позицію Європейського суду з прав людини та справу «Вєренцов проти України» (Заява № 20372/11) від 11 квітня 2013 р., щодо якої Європейський суд з прав людини постановив необхідність забезпечення конституційними гарантіями право на мирні зібрання, які мають передбачати процедуру ï вирішення та, як мінімум, права та зобов'язання щодо їх захисту [4]. У названій справі Європейський суд визначив низку недоліків у національній правовій системі щодо регулювання свободи зібрань, які вилилися у порушення ст. 11 і ст. 7 Конвенції. При цьому було зазначено, що така проблема існує в України «протягом більш ніж двох десятиліть». Європейський суд із прав людини підкреслив необхідність конкретних термінових реформ у законодавстві країни та адміністративній практиці з метою приведення цього законодавства у відповідність з висновками Суду в цій постанові та забезпечення їх відповідності вимогам ст. 7 іст. 11 Конвенції [5].

3 огляду на все вищезазначене, рішення Європейського суду з прав людини у вирішенні питань про мирні зібрання слугує вагомим авторитетом та джерелом для розгляду справ, які знаходяться в судовому провадженні судді. Згідно зі ст. 17 Закону України «Про виконання рішень та застосування практики Європейського суду з прав людини» українські суди під час відправлення правосуддя повинні застосовувати практику Європейського суду з прав людини як джерело права [6]. При цьому обов'язковий характер для судді носять рішення як щодо України, так і по відношенню до будь-якої іншої держави. Ця норма знайшла своє відображення у Кодексі адміністративного судочинства України (КАС), відповідно до ч. 2 ст. 6: «суд застосовує принцип верховенства права з урахуванням судової практики Європейського суду з прав людини» [7]. Наведене положення $\epsilon$ вагомим для нашого аналізу в даній статті, адже тільки адміністративний суд уповноважений на розгляд таких справ про обмеження або забо- 
рону реалізації права на мирні зібрання. У разі виявлення невідповідності рішення адміністративного суду щодо реалізації права приватною особою на свободу мирного зібрання практиці ЄСПЛ, це може слугувати підставою для його скасування.

Як відомо, до обов'язків держави відноситься створення всіх умов і механізмів для можливості реалізації прав та свобод особою, що і $\epsilon$ безперечним доказом правової держави. Але також постає питання, чи покладає ст. 39 Конституції України на державу в особі ii уповноважених органів обов'язок захищати учасників зібрань від можливих неправомірних дій третіх осіб. На поставлене питання слід відповісти чітко. Безперечно, запровадження заходів охорони слугують гарантіями реалізації основоположних прав особою взагалі та права на участь у мирному зібрані зокрема, що випливає зі ст. 3 Конституції України, у якій закріплено «утвердження i забезпечення прав i свобод людини $\epsilon$ головним обов'язком держави». Тож заборона проведення мирного зібрання з посиланням на неможливість забезпечення громадського порядку буде визначено заздалегідь неправомірним, через те що адміністративні органи повинні використовувати усі наявні технічні, організаційні, людські ресурси, щоб забезпечити відповідну охорону для реалізації приватними особами свого права на мирні зібрання. 3 цього приводу можна навести цитату з рішення Європейського суду з прав людини у справі «Бочковський та інші проти Польщі», де зазначено: «Позитивне зобов'язання держави щодо охорони права на свободу зібрань $€$ особливо важливим у випадках, коли йдеться про непопулярні погляди або меншини, оскільки існує велика вірогідність обмеження їх прав» [8, с. 144]. Тому на будь-яку правову країну покладається обов'язок застосовувати обґрунтовані та співмірні заходи для забезпечення можливості проведення мирного зібрання, що також зазначено у справі «Організація платформа «Лікарі за життя» проти Австрії» від 21 червня 1998 р.: «Учасники зібрання повинні мати можливість проводити його, не побоюючись бути підданими фізичному насиллю з боку опонентів; такі побоювання могли б перешкодити публічному висловлюванню суспільно значущих позицій асоціаціями та іншими групами» [8, с. 26] Але трапляються випадки, коли демонстрація втрачає своє мирне значення і виходить з-під контролю, переростаючи в насильницькі прояви. У такому разі для забезпечення громадського порядку та в інтересах національної або громадської безпеки, для запобігання заворушенням чи злочинам, для охорони здоров'я чи моралі або для захисту прав і свобод інших осіб, які не задіяні у протесті, на правоохоронні органи мають покладатися повноваження у виявленні правопорушників та локальне їх припинення. При цьому таке втручання не повинне мати на меті повний розпуск демонстрації, оскільки Європейський суд з прав людини у справі «Станков і Об'єднана організація Македонії «Илинден» проти Болгарії» нагадав: «Перелік винятків з прав на свободу вираження поглядів та зібрань у ст. 10 та ст. 11 Конвенції вичерпний. Визначення цих винятків обмежувальні та повинні тлумачитися у вузькому значенні» [8, с. 64]. Не малозначний той факт, що хоча закон і вповноважує адміністративні органи вжити розумних та належних заходів для забезпечення мирного характеру демонстрацій, однак не вимагає від них забезпечення пев- ного результату, оскільки він залежить від чималої кількості обставин, які не можна передбачити під час проведення таких мирних зборів [8, с. 26].

Отож, виходячи з широкої практики Європейського суду та наявної нормативної прогалини у сфері реалізації права на мирні зібрання в Україні, наразі представлено два законопроекти під № 3587 та № 3587-1 «Про гарантії свободи мирних зібрань» від 2015 р. [9]. Венеціанська комісія вже надала свої рекомендації щодо представлених проектів законодавчого акту про їх відповідність міжнародним договорам, європейським стандартам та цінностям. Загалом, Єврокомісія позитивно оцінює документи, схвально відгукуючись про враховані раніше пропозиції та зауваження, але між тим висновки свідчать про необхідність доопрацювання проектів закону. До загальних порад для обох законопроектів варто віднести вдосконалення понятійного апарату цих положень, а саме звуження визначення терміну «зібрання», щоб забезпечити його відповідність загальноприйнятим стандартам розуміння в Європі (це не просто публічний захід, а зібрання людей з метою вільного висловлення своїх поглядів). Також необхідно ввести термін «спонтанних зібрань» у проект Закону № 3587-1; більш детально регламентувати в положеннях неможливість вчасного й обґрунтованого повідомлення в разі таких зібрань у проекті Закону № 3587, при цьому у ст. 7 [1] слід чітко визначити список зібрань, які не вимагають повідомлення, в тому числі стосовно невеликих та спонтанних. Ст. 2 має бути переглянута в обох законопроектах, у тому числі, відповідно до рекомендацій, необхідно включити до сфери дії майбутнього закону деякі категорії зібрань: зустрічі виборців із кандидатами в депутати та обраними депутатами, кандидатами на пост Президента України не $\epsilon$ винятком і мають охоплюватися поняттям зібрання. Не малозначним щодо висновків Єврокомісії $\epsilon$ порада приведення у відповідність до ст. 39 Конституції України положень, які стосуються підстав обмеження зібрання. І як виняток, накладання обмежень свободи зібрань відноситься тільки до компетенції суддів; повноваження правоохоронних органів стосовно накладання необхідних та пропорційних обмежень без судового наказу мають бути прописані в обох проектах Закону, але зауважити на певні умови та виключний перелік підстав, згідно з якими може бути застосований примус під час таких зібрань [10].

Проводячи аналіз усіх рекомендацій у цій статті, які надала Європейська комісія за демократію через право, ми повністю поділяємо таку думку та маємо на меті акцентувати увагу на кількох додаткових питаннях із цього приводу. Що ще слід зауважити відповідно до наведених проектів закону, так це можливість чіткого та всебічного визначення термінології, яка повинна бути зафіксована в майбутньому законі, тому ми вважаємо, що конкретна норма законопроекту має розширити визначення понять таких як: «громадський порядок», «обмеження права на мирні зібрання», «національна безпека», «форми мирного зібрання», «організатор мирних зібрань», «умови і порядок проведення мирних зібрань», «місце і час проведення», «завчасне повідомлення». На нашу думку, ч. 1 ст. 3 в обох законопроектах $\epsilon$ зайвою, оскільки не несе в собі ніякої цінності для застосування і тлумачення закону з огляду на більш конкретні норми ст. 8 і ст. 9 Конституції Україні. Тим більше, формулювання терміну «інші закони України» 
$\epsilon$ не чітким, тому що в такому випадку це дає можливість обмежити реалізацію права щодо мирних зібрань іншими законами в майбутньому. Для недопущення такого випадку пропонуємо або викласти це положення так, щоб гарантувати вимогу передбачуваності законів та виключити будь-які спроби зловживання і порушення права на свободи зібрань іншими законодавчими актами, або навести у цьому положенні вичерпний перелік існуючих законів, що дозволить збільшити прозорість і передбачуваність закону. У проекті закону № 3587 потрібно детальніше прописати повноваження правоохоронних органів в особі Національної поліції, навести вичерпний перелік підстав та умови, за яких може бути накладена відповідальність і застосований необхідний примус до учасників мирного зібрання, якщо воно втратить свій мирний характер проведення чи переросте в масові зіткнення та безлади, які можуть нести небезпеку для охорони прав третіх осіб. У таких випадках порядок дій правоохоронних органів повинен бути передбачений та докладно викладено в нормах закону. Аналізуючи наведену проблему, радимо взяти до уваги наші рекомендації та гармонізувати обидва проекти закону щодо можливих дій таких органів для обмеження права на мирні зібрання й забезпечити їх відповідність із п. 10 ч.1 ст. 23 Закону України «Про Національну поліцію», де зазначено, що поліція вживає заходів для забезпечення публічної безпеки й порядку на вулицях, площах, аеропортах, інших публічних місцях [11]. Також слід навести ч. 1 ст. 6 проекту Закону № 3587-1, у якому організатор на власний розсуд сам вирішує про повідомлення щодо зібрання відповідний державний орган «у разі необхідності гарантувати безпеку учасників зібрання». Наведене положення зовсім не відповідає ст. 39 Конституції України, де передбачено що «громадяни мають право збиратися мирно, про що завчасно сповіщають органи виконавчої влади чи органи місцевого самоврядування». Тим більше, «гарантія безпеки учасників» не може бути єдиним обґрунтуванням для вимоги повідомлення, адже його метою $€$ : дозволити державі забезпечити всі заходи для полегшення свободи зібрань та охорони громадського порядку, громадської безпеки та створення умов задля недопущення порушення прав інших осіб.

У представлених законопроектах № 3587 i № 3587-1 можна помітити деякі недоробки, які потребують доопрацювання. Загалом, у них наявна позитивна тенденція щодо всебічного врегулювання права на мирні зібрання, що $є$ вагомим питанням для нашої держави і громадськості на сьогодення. Важливо зауважити те, що в цих проектах закону дуже широко регламентовані права й обов'язки як організатора/учасників зібрання, так і державних органів, які забезпечують заходи для втілення такого права в життя. Наведена відповідна форма повідомлення, зокрема у № 3587, визначенні мінімальні строки завчасного сповіщення, яке неодноразово піднімалось під час вирішення справ у судовому провадженні, відповідно до чого Конституційний Суд надав своє рішення за конституційним поданням Міністерства внутрішніх справ України від 19 квітня 2001 р. № 4-рп/2001: «Тривалість строку завчасного сповіщення має бути достатньою для того, щоб органи виконавчої влади чи органи місцевого самоврядування могли визначитися, чи відповідає проведення таких зібрань чинному законодавству, та в разі потреби згідно з частиною другою статті 39 Конституції України, звернутися до суду для вирішення спірних питань» [12]. Вагомого значення надається запровадженню інституту медіації, що дозволить вирішити різні спори у формі переговорів з метою спільного пошуку шляхів вирішення порушених питань без залучення участі суду.

Висновки. Підсумовуючи все вищесказане, можна зробити висновок, що реалізація основоположного права на мирні зібрання, яке надано Конституцією України всім суб'єктам правовідносин без виключення, має бути якомога швидше врегульована та законодавчо підкріплена відповідним спеціальним законом, щоб усунути значну прогалину в національній правовій системі країни. При цьому приймаючи такий закон, нашому парламенту необхідно врахувати всебічність розкриття такої сфери відносин та забезпечення гарантій вільної реалізації свого права як учасниками зборів, так і особами, котрі не беруть участі в заході. Необхідні обмеження або заборона повинна виходити тільки з обґрунтованого рішення суду щодо конкретного зібрання за наявності безперечних доказів, а також за умов недопущення порушення прав третіх осіб чи підриву національної безпеки, територіальної цілісності тощо. Крім того, зазначений в Основному Законі перелік підстав обмежень зібрань $\epsilon$ вичерпним і розширеному тлумаченню не підлягає. Відповідно до ст. 5 Конституції України носієм суверенітету і єдиним джерелом влади в Україні $є$ народ, який здійснює владу безпосередньо і через органи державної влади. Реалізація права «безпосередньої демократії» гарантується ст. 69 Конституції України, згідно з якою народне волевиявлення здійснюється через вибори, референдуми та інші форми. Наявність у головному нормативному акті країни словосполучення «інші форми» слугує доказом позитивних кроків до подальшого розширення прав громадян у бік народовладдя. Завдяки такій нормі громадяни мають можливість брати активну участь у політичному житті країни, в тому числі й у формах мирних зборів, що дозволяє формувати спільну колективну позицію щодо державних рішень та здійснювати безпосередній вплив на функціонування публічних інституцій. Адже саме це слугує наявним підтвердженням демократичної держави, де прийняті сьогодні рішення завтра можуть стати предметом вільного обговорення та сумніву, і тому право на свободу мирного зібрання $\epsilon$ виявом народного суверенітету й громадянського суспільства.

\section{Література}

1. Конституція України: офіц. текст. Київ: КМ, 2018.96с.

2. Мельник Р.С. Право на свободу мирних зібрань: теорія і практика. К., 2015. 168 с.

3. Про практику застосування адміністративними судами законодавства під час розгляду та вирішення справ стосовно реалізації права на мирні зібрання (збори, мітинги, походи, демонстрації тощо) : постанова Пленуму Вищого адміністративного суду України від 21.05.2012 № 6. URL: https://zakon.rada.gov.ua/laws/show/v0006760-12 (дата звернення: 20.01.2020)

4. Справа «Вєренцов проти України»: Рішення Європейського суду з прав людини від 11.04.2013 Заява № 20372/11. URL: https://zakon.rada.gov.ua/laws/show/974_945 (дата звернення: 23.01.2020)

5. Конвенція про захист прав людини i основоположних свобод : Рада Європи від 02.10.2013. URL: https://zakon.rada.gov.ua/laws/show/995_004. 


\section{Проблеми становлення правової демократичної держави}

6. Про виконання рішень та застосування практики Європейського суду з прав людини : Закон України від 23.02.2006 № 3477-IV. URL: https: / zakon.rada.gov.ua/laws/ show/3477-15 (дата звернення: 23.01.2020)

7. Кодекс адміністративного судочинства України від 06.07.2005 № 2747-IV. URL: https: / /zakon.rada.gov.ua/laws/ show/2747-15 (дата звернення: 30.01.2020)

8. Свобода мирных собраний в практике Европейского Суда и Комиссии по правам человека: сб. решений и постановлений / С.С. Дикман, К.И. Терехов; под общ. ред. С.С. Дикмана. М. : РИО «Новая юстиция». 2011. 360 с.

9. Про гарантії свободи мирних зібрань: Проекти Закону № 3587 від 07.12.2015 і № 3587-1 від 11.12.2015: Офіційний портал Верховної Ради України. URL: http: / / w1.c1.rada.gov.ua/pls/zweb2/webproc4_ 1?pf3511=57310 (дата звернення: 20.01.2020).

10. Висновки Венеціанської комісії (Думка № 854/2016). URL: https://supreme.court.gov.ua/userfiles/ CDL_AD_2016_030_2016_10_18.pdf.
11. Про Національну поліцію: Закон України від 02.07.2015 № 580-VIII. URL: https://zakon.rada.gov.ua/ laws/show/580-19 (дата звернення: 2.02.2020).

12. Про офіційне тлумачення положення частини першої статті 39 Конституції України про завчасне сповіщення органів виконавчої влади чи органів місцевого самоврядування про проведення зборів, мітингів, походів і демонстрацій (справа про завчасне сповіщення) : Рішення Конституційного Суду України у справі за конституційним поданням Міністерства внутрішніх справ України від 19 квітня 2001 року № 4-рп/2001. URL: http://ccu.gov.ua/ storinka-knygy/437-pravo-na-myrni-zibrannya (дата звернення: 3.02 .2020 )

Конєв І. $\epsilon .$, студент II курсу юридичного факультету Дніпровського національного університету імені Олеся Гончара 